\title{
KONSELING ANTAR BUDAYA TERHADAP PERKAWINAN BATAK TOBA DAN NIAS DI KECAMATAN SIBABANGUN
}

\author{
Sukatno $^{1}$, Rizky Fardhani Lubis ${ }^{2}$ \\ Bimbingan dan Konseling Universitas Muhammadiyah Tapanuli Selatan \\ sukatno@um-tapsel.ac.id
}

\begin{abstract}
Abstrak: Judul penelitian ini menekankan pada permasalahan yang terjadi pada saat menuju perkawinan pada suku budaya Batak dan Nias. Tujuan yang ingin di capai adalah untuk mengetahui perbedaan perkawinan suku batak dan Nias. Dengan menggunakan penelitian kualitatif, responden yang menjadi obyek penelitian, Mendukung penelitian kualitatitf digunakan tradesi fenomenologi yang fokus pada pengalaman seseorang. Adapun teknik penentuan informan dalam penelitian ini menggunakan teknik purposive sampling, yaitu teknik pengambilan sampel didasarkan atas tujuan tertentu (orang yang betul dipilih memiliki kriteria sebagai sampel). Jenis sumber data yang akan dimanfaatkan oleh peneliti adalah data primer dan data sekunder. Obyek penelitiannya adalah keluarga kawin beda suku dengan beragam variasi sebanyak 3 Pasang Responden dan 4 masyarakat. Wawancara dilakukan selama dua minggu. Temuan yang dapat menjadi sumbangan dalam konseling antar budaya perkawinan beda budaya. Menghadapi persoalan konseling antar budaya, dalam perkawinan beda budaya. Begitu kuatnya hubungan kekeluargaan dalam etnis Nias, sehingga pendapat keluarga selalu dijadikan pertimbangan untuk mengambil keputusan.
\end{abstract}

Kata kunci :Konseling, Perkawinan, SukuBatak ,Nias

Abstract: The title of this study emphasizes the problems that occur at the time of marriage in the tribes of Batak and Nias cultures. The goal to be achieved is to find out the differences in the marriage of the Batak and Nias tribes in Sibabangun District. By using qualitative research, respondents are the object of research. Supporting qualitative research is used in the phenomenology tradition that focuses on one's experience. The technique of determining the informants in this study using purposive sampling technique, namely the sampling technique is based on specific goals (people who are really selected have criteria as a sample). The types of data sources that will be utilized by researchers are primary data and secondary data. The object of the research is families of different ethnic groups with various variations as many as 3 pairs of respondents and 4 communities. Interviews were conducted for two weeks. Findings that can contribute to counseling between cultures of different cultures.Facing the issue of inter-cultural counseling, in different cultures. So strong is the family relationship in Nias ethnic groups, so that family opinions are always taken into consideration for making decisions.

Keywords: Counseling, Marriage, Batak ,Nias Tribes 


\section{PENDAHULUAN}

Perkawinan adalah ikatan sosial atau ikatan perjanjian hukum antar pribadi yang membentukhubungan kekerabatan dan yang merupakan suatu pranata dalam budaya setempat yang meresmikan hubungan antar pribadi yang biasanya intim dan seksual. Perkawinan umumnya dimulai dan diresmikan dengan upacara pernikahan. Umumnya perkawinan dijalani dengan maksuduntuk membentuk keluarga. Pernikahan beda budaya adalah suatu pernikahan yang terjadi antara pasangan yang berasal dari latar belakang budaya yang berbeda, dimana terdapat penyatuan pola pikir dan cara hidup yang berbeda, yang bertujuan untuk membentuk rumah tangga yang bahagia dan kekal berdasarkan Ketuhanan Yang Maha Esa.

Peristiwa ini membawa masyarakat saling terikat dengan suku-suku yang berbeda. Penerimaan terhadap budaya atau suku lain akan membuat seseorang berpeluang besar diterima oleh keluarga pasangannya. Mereka akan merasa bahwa budayanya diterima dan dihargai. Hal sebaliknya dapat terjadi, yaitu apabila seseorang resisten dan menolak budaya calon pasangannya. Sebagai contoh, apabila seseorang hendak menikah dengan pasangan yang berasal dari suku batak, maka sangat besar harapan dari keluarga pasangannya itu bahwa perkawinan akan dilaksanakan menurut budaya mereka.

Sistem perkawinan adat merupakan salah satu tradisi dari suatu suku bangsa yang masih berlaku dalam masyarakyat adat Indonesia dalam melangsungkan perkawinan. Salah satu suku bangsa di wilayah Negara Kesatuan Republik Indonesia yang masih mempertahankan tradisi perkawinan adat adalah suku Nias. Masyarakat Adat Nias merupakan kelompok masyarakat yang terbentuk dari kesatuan masyarakat komunal yang kuat (kampung, marga, keluarga besar). Untuk mengatur kehidupan bersama dalam suatu ikatan, masyarakat adat Nias, diatur oleh suatu aturan adat (goigoi hada), yang harus ditaati oleh setiap warganya. Dalam Perkawinan adat Nias, laki-laki dan perempuan memiliki perbedaan kedudukan, sejak pra-perkawinan hingga di dalam perkawinan bahkan hingga berakhirnya, apabila kemudian perkawinan tersebut berakhir. Perbedaan kedudukan ini dipengaruhi oleh kedudukan perempuan dalam status sosialnya di dalam pola kehidupan masyarakat adat Nias. Dalam masyarakat Nias, perempuan memiliki status yang lebih rendah dibandingkan laki-laki, karena laki-laki dianggap sebagai pemimpin dan lebih kuat. Oleh karena itu di segala lini kehidupan sosial dan budaya, perempuan tidak banyak ikut berperan.

Di Sibabangun, fenomena perkawinan beda budaya dalam keluarga kawin beda etnis yaitu batak dan nias menarik untuk diteliti lebih lanjut, terutama keluarga yang melibatkan etnis Batak dan etnis Nias. Sibabangun memiliki sejarah panjang hubungan antara etnis Batak dan etnis Nias yang penuh dengan konflik. Ada beberapa perkawinan yang beda suku tidak berjalan dengan harmonis dan ada juga yang harmonis, semua tergantung dengan cara masing-masing pasangan berintegrasi terhadap pasangan masing-masing meskipun beda budaya.

Konseling Antar budaya (cross culture counseling) mengandung pengertian hubungan yang terjadi dalam proses konseling yang melibatkan konselor dan konseli yang berasal dari latar belakang budaya yang berbeda, dan karena itu proses konseling sangat rawan oleh terjadinya bias-bias budaya pada pihak konselor yang mengakibatkan konseling tidak berjalan efektif. Menurut penelitian yang dilakukan agar berjalan efektif, maka konselor dituntut untuk memiliki kepekaan budaya dan melepaskan diri dari bias-bias budaya, mengerti dan dapat mengapresiasi diversitas budaya, dan memiliki keterampilan-keterampilan yang responsif secara cultural. Dengan demikian, maka konseling dipandang sebagai "perjumpaan budaya" (cultural encounter) antara konselor dan klien. Konsep mengenai konseling antar budaya cenderung akan menekankan unsur budaya dan kebudayaan yang meliputi tradisi, kebiasaan, nilai-nilai, norma, bahasa, keyakaninan yang telah terpola dalam suatu masyarakat dan diwariskan turun temurun. Konsep ini pula yang kemudian memberikandefinisi-definisi awal mengenai konseling antar budaya.

Perbedaan budaya bisa terjadi pada ras atau etnik yang sama ataupun berbeda. Oleh sebab itu definisi konseling antar budaya yang dapat dijadikan rujukan adalah sebagai berikut. Konseling antar budaya adalah hubungan konseling yang melibatkan para peserta yang berbeda etnik atau kelompok-kelompok 
minoritas; atau hubungan konseling yang melibatkan konselor dan konseli yang secara rasial dan etnik sama, tetapi memiliki perbedaan budaya yang dikarenakan variabel-variabel lain seperti seks, orientasi seksual, faktor sosioekonomik, dan usia.

\section{METODE PENELITIAN}

Penelitian ini adalah penelitian dasar yang memiliki tujuan untuk mencari pemahaman mengenai suatu masalah Tujuan tersebut dapat dicapai dengan tradisi fenomenologi. Penelitian ini dapat dikaitkan dengan tradisi fenomenologi sebagai salah satu cara untuk memahami teori konseling. , fenomenologi merupakan sebuah tradisi yang fokus pada pengalaman seseorang, termasuk pengalamannya dengan orang lain. Fenomenologi melihat objek-objek dan peristiwa-peristiwa dari perspektif seseorang sebagai ahli menyatakan, tidak ada skema konseptual di luar aktualitas pengalaman langsung yang mampu menyibak kebenaran, daripada pengalaman yang disadari individu sebagai alur untuk menemukan realita.

Sebuah fenomena adalah penampakan dari sebuah objek, peristiwa atau kondisi dalam persepsi seseorang. Manusia memberi makna pada sesuatu yang ada di dunia ini, tetapi tidak ada seorang pun yang mengalami sesuatu di luar dunia ini. Jadi, sesuatu dan kejadian merupakan sebuah hubungan atau memberi dan menerima atau budaya yang saling mempengaruhi

\section{HASIL DAN PEMBAHASAN}

Dalam penelitian ini, penggunaan subyek yang berasal dari budaya Batak Toba dan Nias yang berada di Kecamatan Sibabangun. Karenanya subyek memiliki budaya yang berbeda. Dengan perbedaan budaya yang ada melalui penelitian ini subyek mengungkapkan permasalahan yang dialaminya saat sebelum dan sesudah perkawinan. Dan peneliti membahas mengenai konflik yang ada dalam perkawinan beda suku budaya. Dengan adanya perjumpaan budaya, ketika subyek dengan konseling melakukan konseling antar budaya terhadap masyarakat. Budaya batak yang memiliki perbedaan dengan budaya Nias ,dengan demikian maka dalam proses konseling Antar Budaya ini akan muncul berbagai permasalahan karena perbedaan budaya yang ada. Berdasarkan hasil wawancara selama penelitian yang dilakukan oleh peneliti terhadap subyek maupun key informan, berikut pembahasan hasil reduksi data yang dibutuhkan dalam penelitian sesuai dengan tujuan dilakukannya penelitian mengenai permasalahan dalam konseling antar budaya terhadap perkawinan suku budaya batak toba dan nias di kecamtan Sibabangun, yaitu :

\section{Konsensus (Kesepakatan awal sebelum pernikahan)}

Konsensus merupakan kesepakatan awal sebelum pernikahan secara resmi dinyatakan dalam ikatan secara hukum maupun agama. Jika terdapat konsensus dalam sebuah pernikahan, menunjukkan bahwa pernikahan tersebut betul-betul dipersiapkan secara matang oleh setiap pasangan. Melihat aspek analisis mengenai kesepakatan ini, hampir semua pasangan yang menjadi informan penelitian, mengakui telah melakukan kesepakatan dengan pasangan masingmasing ketika sebelum meresmikan pernikahan. Proses terjadinya suatu kesepakatan bisa cepat, tetapi tidak menutup kemungkinan melalui proses yang lama. Para responden mengatakan, agama menjadi landasan mutlak kehidupan rumah tangga mereka. Kalaupun berbeda budaya, agama yang dianut oleh keluarga tetap harus satu. Inilah kesepakatan yang diakui oleh beberapa responden tersebut yang dapat menguatkan niat mereka untuk tetap mempertahankan hubungan tersebut hingga jenjang pernikahan. Selain itu Mereka memilih melakukan langkah-langkah persuasif untuk meredam ketegangan akibat pertentangan keluarga yang tidak menyetujui perkawinan berbeda etnis tersebut.

Responden menyadari akan kesulitan yang muncul melihat latar belakang budaya yang berbeda. Mereka memilih mencari pijakan yang kuat kehidupan rumah tangga pada agama. Proses kesepakatan dengan agama sebagai landasan utama dapat cepat terjadi, terutama jika kedua pihak telah memiliki agama yang sama sejak lama, seperti pasangan keluarga bapak Mando dan Bapak Tarihoran, yang menjadikan agama sebagai landasan keluarga mereka. Dan dari ungkapan Bapak Gester yang mau pindah agama mengikuti pasangannya dan tidak lama kemudian keluarga pasanagannya memberikan restu kepadanya. Dari ungkapan 
responden tersebut, dapat terlihat bahwa perbedaan budaya menjadi tidak penting lagi dibandingkan kesamaan agama yang bagi mereka bermakna lebih dalam, karena agama dianggap demikian penting sebagai pedoman dalam menjalani kehidupan.

\section{Pola pikir terbuka terhadap budaya pasangan}

Komponen budaya yang paling dominan adalah kepercayaan, nilai dan norma. Ketiga hal tersebut seringkali tanpa sadar telah menjadi suatu bentuk budaya yang diwariskan oleh leluhur, dan menjadi sebuah ekspektasi dari akar budaya yang diharapkan dapat terus diturunkan pada generasi selanjutnya. Tetapi kondisi masyarakat yang semakin terbuka dan bebas untuk berinteraksi dengan siapapun dapat memberikan pengaruh terhadap warisan kepercayaan, nilai dan norma dari leluhur. Bahkan komponenkomponen tersebut dapat mengalami perubahan yang signifikan, sehingga jejak leluhur dapat tersamar.

Hal ini terutama terjadi jika menyoroti mengenai peran suami dan istri dalam konteks pernikahan beda etnis. Etnis Batak Toba maupun etnis Nias, memiliki perbedaan makna tentang peran istri dan suami dalam sebuah relasi pernikahan. Ketika individu memutuskan melakukan pernikahan, peran yang akan dijalaninya dan yang akan dijalani pasangannya dapat berubah sesuai dengan kondisi yang diharapkan. Dalam hal ini peran-peran tersebut melalui proses adaptasi. Bahkan peran-peran yang dijalankan, yang seharusnya sesuai dengan kepercayaan, nilai dan norma yang diwariskan oleh budayanya, dapat tereliminasi tanpa disadari.

Mayoritas pasangan yang memutuskan melakukan pernikahan antar etnis harus memiliki pola pikir terbuka terhadap budaya yang dibawanya dan dibawa oleh pasangannya, termasuk kepercayaan, nilai dan norma. Jika kedua pihak tidak memiliki pola pikir terbuka, akan terjadi pemaksaan kehendak untuk mempraktikkan kepercayaan, nilai dan norma yang dianut oleh pasangannya, sehingga kemungkinan langgengnya sebuah pernikahan tidak akan ada. Sebagaimana sikap yang dijalankan oleh pasangan keluarga bapak Mando dan pasangan keluarga bapak Tarihoran.

\section{Kesamaan atau kesalahpahaman}

Kesalahpahaman ini dikarenakan munculnya kecemasan dan ketidakpastian dalam pertemuan budaya. Faktor-faktor yang dapat menyebabkan munculnya ketidakpastian dan kecemasan. Faktor-faktor tersebut adalah motivasi, pengetahuan dan tindakan. Jika motivasi yang muncul adalah agar keturunannya tidak bercampur dengan etnis lain, maka kesalahpahaman budaya akan muncul, terutama dalam pembentukan sebuah keluarga kawin beda suku. Sedangkan pengetahuan yang minim mengenai budaya lain, dibandingkan budaya diri sendiri, akan menghambat interaksi mendalam antar etnis. Hal ini akan termanifestasi dalam bentuk perilaku atau tindakan yang ditempuh seseorang ketika berhubungan dengan orang lain dalam budaya yang berbeda.

Manusia hidup dalam sebuah komunitas yang mempunyai kebijakan tentang sesuatu yang mereka miliki bersama, dan perkawinan merupakan satusatunya jalan untuk membentuk kebersamaan itu. Perkawinan menciptakan atau membuat segala kebimbangan menjadi lebih pasti. Perkawinan merupakan penyatuan dua pribadi yang unik, dengan membawa sistem keyakinan masing-masing berdasarkan latar belakang budaya serta pengalamannya. Perbedaan-perbedaan yang ada perlu disesuaikan satu sama lain untuk membentuk sistem keyakinan baru bagi sebuah keluarga. Proses inilah yang seringkali menimbulkan ketegangan. Meskipun budaya yang dimiliki sebagai latar belakang tidak sama, tetapi ada beberapa makna dalam budaya satu dengan lainnya yang sama. Hal ini tampak dalam penelitian yang kemudian dapat diketahui, bahwa ada satu kesamaan antara budaya Batak Toba dengan budaya Nias. Paling tidak prinsip kesamaan ini dapat menimbulkan satu kesepakatan untuk memutuskan jalan keluar dari satu persoalan. Kesamaan dari para responden yang terlibat dalam penelitian ini adalah sikap hormat kepada orang tua dan keluarga lainnya. Terutama jika hubungan beda budaya tersebut mendapatkan pertentangan dari awal.

Pernyataan dari ketiga responden di atas menggambarkan, bagaimana budaya yang berbeda memiliki sikap yang sama mengenai 
hubungan dengan orang tua dan keluarga besar. Sikap menghargai pendapat keluarga besar sangat dirasakan sebagai sebuah bentuk simpati. Sehingga tidak semata-mata kehendak pribadi mengalahkan pendapat keluarga besar. Kesalahpahaman yang paling menonjol dalam Perkawinan antar budaya yang dialami oleh keluarga kawin beda budaya lebih dikarenakan berkembangnya stereotip mengenai budaya tertentu.

\section{Penyesuaian}

Studi tentang pasangan antar budaya, memunculkan tema seputar pengalaman pasangan kawin beda suku dalam usaha untuk saling menyesuaikan diri ketika menghadapi persoalan perkawinan pada umumnya dan penyesuaian diri ketika menghadapi persoalan yang menyangkut budaya. Yang paling menonjol dalam kasus perkawinan campuran adalah perbedaan ekspektasi tidak hanya oleh kedua individu, tetapi juga anggota keluarga besar masingmasing individu. Bahkan ketika pasangan tersebut menyatakan untuk tetap mempertahankan hubungan hingga ke jenjang lebih serius. Penyesuaian dengan keadaan, bahwa keluarga besar tidak setuju, selanjutnya ditempuh sikap untuk meredam ketegangan dengan berupaya melakukan pendekatan secara persuasif kepada keluarga.

Tindakan yang dilakukan oleh Responden dalam penyesuaian diri dengan keadaan yang menentang hubungan antar budaya cukup memiliki makna yang sangat dalam, terutama jika berkaitan dengan religi dan keyakinan. Jika kemudian penyesuaian masuk dalam ranah keluarga, tampak perbedaan jalan yang ditempuh beberapa pasangan. Responden 1 dan 2 memilih untuk tidak berusaha saling menyesuaikan dengan budaya pasangannya, karena menurut mereka patokan yang jelas dalam keluarga adalah dasar agama.

\section{Penyelesaian Konflik}

Kesadaran tentang adanya kekeliruankekeliruan dalam hubungan lintas budaya, merupakan langkah maju pertama yang besar. Dan menerima fakta, bahwa pendirianpendirian seseorang tidak selamanya benar dibandingkan pendirian orang lain merupakan suatu langkah maju lainnya. Budaya membantu seseorang memahami wilayah atau ruang yang ditempatinya. Budaya memudahkan kehidupan dengan memberikan solusi-solusi yang telah disiapkan untuk memecahkan masalahmasalah, dengan menetapkan pola-pola hubungan, dan cara-cara memelihara kohesi dan konsensus kelompok. Perbedaan budaya dapat menyebabkan konflik, dan ketika konflik terjadi, latar belakang budaya dan pengalaman dapat berpengaruh pada bagaimana seseorang mencari solusi. Konflik dapat dilihat sebagai sebuah kesempatan, yang dianggap sebagai ketidaksesuaian tujuan, nilai-nilai, harapan, proses ataupun hasil di antara dua atau lebih individu maupun kelompok. Melihat kondisi perkawinan campuran antar budaya, hampir semua responden dan iforman juga memiliki pendapat masing-masing, menyatakan tidak ada konflik antara mereka dengan pasangan, yang berlatar belakang budaya.

\section{KESIMPULAN}

Etnis Batak Toba maupun etnis Nias, memiliki perbedaan makna tentang peran istri dan suami dalam sebuah relasi perkawinan. Ketika individu memutuskan melakukan perkawinan campuran, peran yang akan dijalaninya dan yang akan dijalani pasangannya dapat berubah sesuai dengan kondisi yang diharapkan. Dalam hal ini peran-peran tersebut melalui proses adaptasi. Bahkan peran-peran yang dijalankan, yang seharusnya sesuai dengan kepercayaan, nilai dan norma yang diwariskan oleh budayanya, dapat tereliminasi tanpa disadari. Mayoritas pasangan yang memutuskan melakukan kawin campur harus memiliki pola pikir terbuka terhadap budaya yang dibawa oleh pasangannya, termasuk kepercayaan, nilai dan norma. Jika kedua pihak tidak memiliki pola pikir terbuka, akan terjadi pemaksaan kehendak untuk mempraktikkan kepercayaan, nilai dan norma yang dianut oleh pasangannya, sehingga kemungkinan langgengnya sebuah perkawinan ibarat jauh panggangan dari api.

Dalam konteks perkawinan beda budaya, kebiasaan dapat mempengaruhi penilaian keluarga besar terhadap seseorang yang akan dijadikan pendamping hidup. Begitu kuatnya hubungan kekeluargaan 
dalam etnis Nias, sehingga pendapat keluarga selalu dijadikan pertimbangan untuk mengambil keputusan. Diperlukan komitmen luar biasa oleh pasangan kawin beda suku, sehingga segala bentuk kesalahpahaman dapat lebih mudah teratasi. Termasuk ketika masing-masing pihak melakukan penyesuaian agar perkawinan dapat terjadi dan mendapat lampu hijau dari keluarga besar. Dari upaya ini kemudian dapat ditemukan kesamaan dari etnis Batak dan etnis Nias. Dengan keteguhan memilih pasangan yang tepat meskipun berbeda budaya, maka kedua pihak sama-sama berupaya untuk meyakinkan keluarga besar masing-masing. Hal ini terutama dikuatkan dengan landasan agama, terutama bagi pasangan yang memiliki agama sama.

Ketika seseorang dihadapkan pada suatu persoalan, secara tidak sadar akan muncul sifat dasar yang melekat. Sifat dasar ini dibentuk dari lingkungan tempat ia dibesarkan. Hal ini akan berpengaruh pada suatu hubungan dengan orang lain terutama seseorang yang memiliki akar budaya yang berbeda. Kepasrahan atau menyerahkan keputusan pada pasangan, mendominasi pembicaraan, menonjolkan cara-cara budayanya untuk menyelesaikan masalah, seringkali menjadi petunjuk bagi seseorang untuk menilai pasangannya. Budaya Nias dan budaya Batak terdapat nilai-nilai budaya yang relative sama, yaitu sikap kepada keluarga besar. Kemiripan tersebut tampak menonjol dalam sikap yang diterapkan oleh keluarga-keluarga kawin beda suku. Falsafah yang terkandung dalam pengalaman spiritual sejak kecil tumbuh dalam lingkungan masing-masing, dirasakan oleh setiap pasangan tidak memiliki perbedaan yang ekstrim. Seperti sikap hormat kepada orang tua dan berinteraksi secara dekat dengan keluarga besar lainnya, tidak hanya dalam konteks bisnis atau demi pekerjaan tetapi interaksi yang memiliki makna lebih dalam. Karena masing-masing pihak, keluarga kawin beda suku, mengakui bahwa meskipun telah memiliki keluarga sendiri tetapi bukan berarti putus hubungan kekerabatan dengan anggota keluarga yang lain. Meskipun berada dalam kondisi keluarga kawin beda suku etnis Batak Toba dan etnis Nias, ternyata setiap keluarga memiliki aturan masingmasing berdasarkan latar belakang tidak hanya budaya, tetapi juga lingkungan masing-masing, latar belakang pendidikan, dan motivasi terjadinya perkawinan.

\section{DAFTAR PUSTAKA}

Adhiputra, A.A.N. 2013. Konseling Lintas Budaya. Yogyakarya: Graha Ilmu.

Burhan Bugin,2007 "Penelitian Kualitatif”, Jakarta: Kencana Prenada Media Group

Dodd, Carley H. Dynamics of Intercultural Communication (Fifth Edition). USA:The McGraw-Hill Companies, Inc., 1998.

Erwinsyahbana, T. 2017. Jurnal Sistem Hukum Perkawinan pada Negara Hukum Berdasarkan Pancasila, Surakarta.

Harahap, R.E. 2010.Penyesuaian Perkawinan pada Pasangan yang Berlatar Belakang Etnis Batak dan Etnis Jawa, Skripsi,( Institut Agama Islam Negeri (IAIN) Purwokerto).

Syahran,R. 2017 “ Konseling Lintas Budaya Dalam Kepekaan Budaya Kaili”, Konseling \& Psikoedukasi.

Lustig, Myron, dan Jolene Koester. 2003 Intercultural Competence, Interpersonal Communication Across Cultures (Fourth Edition). USA: Allyn \& Bacon Pub., .

Margaretha, L. Dkk. 2016. Jurnal “Pelestarian Nilai-Nilai Civic Culture dalam Memperkuat Identitas Budaya Masyarakat: Makna Simbolik Ulos dalam Pelaksanaan Perkawinan Masyarakat Batak Toba di Sitorang”,(Bandung Universitas Pendidikan Indonesia)

Murtadho, $2009 \quad$.konseling perkawinan.Semarang; Walisongo Press

Martin, Judith N., \& Thomas K. Nakayama. 2004. Intercultural Communication in 
Contexts (Third Edition). New York: The McGraw-Hill Companies, Inc.,.

Mulyana, Deddy. 2003. Ilmu Komunikasi Suatu Pengantar. Bandung: Remaja Rosdakarya,

Lappies,PA. Dkk. 2018 Penerapan Konseling Lintas Budaya dan Studi Feminis Poskolonial Terhadap Penindasan Budaya Patriarki , (Jurnal penelitian dan pengembangan penelitian).

Nasution, S. 1992 Metode Penelitian Naturalistik Kualitatif. Bandung: Tarsito

Rullyanti, 2008 Komunikasi antar budaya dalam keluarga kawin campur Jawa-Cina di Surakarta, Tesis. Surakarta

Savitri, N. Dkk.2012“ Diskiminasi dalam hukum perkawinan ( penelitian atas hukum perkawinan adat suku Nias )" Jurnal. Bandung Fakultas Hukum Universitas Katolik Parahyangan

Sitorus, LS. Dkk. “ Tata Cara Pernikahan Masyarakat Nias di Desa Onowaembo Kecamatan Lahomi Kabupaten Nias" History Education FKIP-University of Riau

Sugiyono, 2010, "Metode penelitian kuantitatif, kualitatif,dan $R A D$ ”,Bandung, Alfabeta 